\title{
Evaluation of Pollen Quality and Self-Fertility in Selected Cultivars of Asian and European Pears
}

\author{
Monika BIENIASZ ${ }^{1 *}$, Tomas NECAS ${ }^{2}$, Ewa DZIEDZIC ${ }^{1}$, \\ Ivo ONDRASEK ${ }^{2}$, Bozena PAWŁOWSKA ${ }^{3}$ \\ ${ }^{1}$ University of Agriculture in Kraków, Department of Pomology and Apiculture, 29 Listopada 54, 31-425 Kraków, \\ Poland;monika@ogr.ur.krakow.pl(*correspondingauthor); ewa@ogr.ur.krakow.pl \\ ${ }^{2}$ Mendel University in Brno, Faculty of Horticulture in Lednice, Department of Fruit Growing, Valtická 337, Lednice 69144, \\ CzechRepublic;necast@zf.mendelu.cz;ivo.ondrasek@zf.mendelu.cz \\ ${ }^{3}$ University of Agriculture in Kraków, Department of Ornamental Plants, 29 Listopada 54, 31-425 Kraków, Poland; ropawlow@cyf-kr.edu.pl
}

\begin{abstract}
Asian pears have become increasingly popular in the European market, but their cultivation history in Europe is rather short. Pear is a demanding species in terms of pollen - donor cultivar. The self-fertility phenomenon in Asian pear cultivars is not currently known. The study was conducted in a 6-year pear orchard (of 23 Asian and 5 European cultivars) at the Mendel University in Lednice (Czech Republic). The following traits were assessed: number of pollen grains, pollen viability, pollen grain germination, self-fertility and the pollen germination index (PGI). European cultivar - 'Clapp's Favourite' and Asian cultivars - 'Zao Su Li', and 'Shinko' were characterized by the highest number of pollen grains (over 50,000 grains). Asian cultivar 'Dangshansu Li' had the lowest number of pollen grains (less than 10,000 grains). The pollen viability of Asian pears ranged between 90 and 100\%. Among European pears, 'Williams Bon Chrétien' and 'Clapp's Favourite' exhibited the highest pollen viability (90\%), while the lowest viability was observed for the pollen of cultivars 'Beurré Bosc' and 'Alexander Lucas' pear (60-70\%). Additionally, it was found that the germination capacity of the latter two cultivars was very weak (40-70\%). After open- pollination all investigated cultivars exhibited greater pollen germination index (PGI) comparing to selfpollination. After the cross-pollination the percentage of pollen tubes below the $20 \%$ value at half the length of the pistil suggested a strong incompatibility between the crossed cultivars. The results clearly showed that none of the Asian cultivars are self-fertile, and they require a pollen - donor to produce fruits.
\end{abstract}

Keywords: pollen germination index, pollen tube, pollination, self-incompatibility

\section{Introduction}

Modern fruit growing is searching for new species that would increase fruit assortment. Introducing new species to the commodity farming should always be preceded by basic research and acquired knowledge should be used in orchard planning. For several years, Asian pears have been increasingly popular and commercially grown in $\mathrm{New}$ Zealand, Chile, and the United States, but their cultivation history in Europe is rather short (Honty et al., 2003). Asian pears (Pyrus bretschneideri Redh., P. serotina Redh., $P$. ussuriensis Maxim) are grown mainly in China, Japan and Korea (Pitera and Odziemkowski, 2004). These pears have recently begun to be marketed to consumers who are not of
Asian origin (Li, 2002). Europeans have little experience with the production of Asian pears. The European market for Asian pears is rather new, though interest is growing (Pitera and Odziemkowski, 2004).

Pear is a demanding species in terms of pollen - donor cultivar selection. The sharp and weight of valuable Asian pear fruits depend on the presence of seeds and thus on pollination events (Jacquemart, 2007). In European pear flowers the stamens mature earlier than the anthers (protogyny) (Konarska et al., 2005). Its flowers contain more nectar from apple blossoms (1.3-3.2 $\mu \mathrm{l}$ vs. 0.4-0.6 $\mu \mathrm{l})$, but sugar content in nectar is lower (9.6-10.8\% vs. 28.336.4\%) (Farkas et al., 2002a; 2002b; Quinet et al., 2016). As reported by Konarska et al. (2005), the secretion of nectar in pear flowers lasted 3 days in Polish conditions. The mass of nectar released during the whole life of the flower was on average $2.47 \mathrm{mg}$ and the concentration of sugars in the 
376

nectar was on average $12.8 \%$. The authors reported that the nectar was watery and quickly dried. These characteristics made the pear flowers unattractive to pollen - donors. The attractiveness of the flowers is also related to the amount of pollen produced, but in this case pear trees are also inferior to apple trees (Quinet et al., 2016).

Pollen quality is also important in the fruit production, i.e., pollen must be characterized by good viability and a high germination capacity. Pollen grains with higher protein and amino acid content are characterized by a better viability and are more attractive to bees (Farkas and OroszKovács, 2004). In order to obtain good fruit quality, pear blossoms must be abundantly pollinated with pollen, and additionally, a high number of pollinating insects is necessary, most frequently honey bee (Benedek, 2003). Experiments carried out by Maccagnani et al. (2003) and Monzón et al. (2004) showed that solitary bee, as Osmia cornuta, can also be good pollen - donor in pear orchards. Currently, the buff-tailed bumblebee is increasingly being used as effective pollen - donor (Zisovich et al., 2012).

Metaxenia has been identified in the pear tree, which means that the pollen of the pollen - donor cultivar affects the characteristics of the resulting fruit. Shin et al. (1988) reported that the fruit weight and number of seeds in the fruits were smaller in the Asian pear cultivar Niitaka immediately after pollination with 'Imamuraaki' and 'Okusanian' cultivars than that of other pollen sources. Moreover, fruits tended to have an oblong shape.

Self-fertility is an important characteristic of each cultivar; self-fertile cultivars are sought in terms of production, as they facilitate agriculture engineering and fruit harvest. Self-fertility trait is rare in European pears, and for this reason pollinating cultivars are planted in orchards. Thus far, the phenomenon of self-fertilization of Asian pear cultivars has been little known (Hiratsuka et al., 2012). Pollination is a very critical factor in self-incompatible and very early-flowering species or cultivars. In pear (Pyrus sp.), similarly as in other genera of the family Rosaceae, the majority of cultivars are self-incompatible. Gametophytic SI (GSI) is the most widespread self-incompatibility system. It means that phenotype of the pollen is determined by its own haploid genotype. Pollen tube growth is arrested in the style if the pollen has an $S$-allele in common with one of the two $S$-alleles in the style (Jacquemart 2006; Jacquemart et al. 2007). Effective pollination is not only dependent on the genotype of both cultivars, but also on the essential characteristic, i.e., the overlap of flowering time of both cultivars. The stigma is receptive, i.e., it receives pollen and allows it to germinate for a short period of time (Sanzol $e t$ al., 2003a,b).

Aim of this study was evaluation of Asian and European pear cultivars in respect of self-fertility and pollen quality. The results of the studies will answer some important questions: (i)What is the pollen yield of the pear cultivar, calculated on the base of the number of pollen grains in the flower? (ii) Which of the studied cultivars are characterized by the highest germination and ability for germination (iii) Are the Asian pear cultivars characterized by self-fertility? (iv) Which of the crossed pairs of pear cultivars are the most compatible?

\section{Materials and Methods}

\section{Plantmaterial}

The study covered 23 cultivars of Asian pear and 5 cultivars of European pear growing in a 6-year-old orchard in the Faculty of Horticulture, Mendel University in Lednice (Czech Republic): 'Beurré Bosc', 'Chojuro', 'Hosui', 'Hood', 'Jin Hua', 'Ju Li', 'Kieffer', 'Kumoi', 'Clapp's Favourite', 'Conference', 'Kum Ghant Chu', 'Alexander Lucas', 'Man San', 'Mramornaja', 'Mut Chen', 'Nijisseiki', 'Ping Guo Li', 'Pung Su', 'Sha Li', 'Shinseiki', 'Shinko', 'Dangshansu Li', 'Sirinskaja', 'Xue Hua Li', 'Williams Bon Chrétien', 'Wujiu Xiang', 'Ya Li', 'Zao Su Li'. The study was conducted for two growing seasons, in the years 2015 and 2016. Orchard experiments were carried out on 4 trees of each cultivar; 30 flowers of the combined pollination were collected for microscopic observations.

\section{Evaluation of pollen quality}

Ten closed anthers were collected to Eppendorf tubes from randomly selected blossoms of pear cultivars to calculate the number of pollen grains. The anthers were dried at $25{ }^{\circ} \mathrm{C}$ for $24 \mathrm{~h}$. The dried open anthers were inoculated with $1 \mathrm{ml}$ of aqueous eosin solution and shaken on Vortex for 30 seconds, and then $0.2 \mathrm{ml}$ solution was taken and applied to a Bürker hemocytometer. Pollen grains were counted in a Zeiss Axio Imager M2 light microscope at $10 \times$ magnification (objective). The number of anthers in the flower was also counted in order to determine the number of pollen grains in the flower. The quality of pollen of Asian and European pear cultivars was assessed on the basis of pollen viability and germination capacity and the number of pollen grains in the flower. The pollen viability was assessed according to the colour method by Alexander (1969). Pollen was collected from the freshly open flowers, seeded on glass slides and Alexander's dye was applied. This dye stains viable pollen grains a fuchsia colour and dead grains green. The pollen germination capacity was determined on the basis of pollen germination in vitro on agar media $(0.6 \%$ agar) supplemented with $10 \%$ sucrose. Pollen from freshly opened flowers was plated on Petri dishes with the above-mentioned medium; the dishes were closed and incubated at $24^{\circ} \mathrm{C}$ for 24 hours.

\section{Evaluation of self-incompatibility of pear cultivars}

An experiment was carried out in the orchard, that included two combinations of flower pollination, to evaluate self-fertility of pear cultivars:

a. free pollination - flowers left for free pollination (control)

b. pollination with own pollen - agrotextile insulators were applied on flowers in the balloon stage and after flower opening, manual pollination was carried out with own pollen.

For both combinations of pollination, the pistils were collected after the fall of corolla petals, fixed in the FAA reagent [formalin : acetic acid : alcohol $80 \%(1: 1: 8)$ ], then the preparations were transferred to $80 \%$ alcohol after $24 \mathrm{~h}$. The plant material was macerated for $12 \mathrm{~h}$ in $30 \% \mathrm{NaOH}$ for aniline blue staining of the preparations. Subsequently, after clearing the tissue with $6 \% \mathrm{H}_{2} \mathrm{O}_{2}$ and $\mathrm{H}_{2} \mathrm{O}$ rinsing, the 
pistils were stained with aniline blue for about $6 \mathrm{~h}$, followed by observations of pollen tube overgrowth through the pistil styles using a Zeiss Axio Imager M2 fluorescence microscope and ultraviolet light of a wavelength of about $356 \mathrm{~nm}$. Under these conditions, callose fluoresces bright yellow-green and contrasts strongly with the bluish or grayish fluorescence of the stylar tissue. The pollen tubes are outlined by a callose lining and irregularly spaced callose plugs (Martin 1959).

In the next stage of the self-fertility assessment experiment, selected Asian cultivars were only selfpollinated to determine the potential for growing these cultivars in one-cultivar units. Flower pollination and microscopic observations were conducted according to the methods described above. The pollen grain germination index (PGI) was used in self-fertile and self-incompatible evaluation, according to Matsuzawa (1983): PGI = $(b+2 c+3 d+4 e) /(a+b+c+d+e)$, where: $a-$ number of pistils with pollen grains, $b-$ number of pistils, in which pollen grains do not germinate, $c$ - number of pistils, in which pollen grains germinate on the stigma, $\mathrm{d}$ - number of pistils, in which pollen tubes enter the style tissue, $\mathrm{e}$ - number of pistils, in which pollen tubes penetrate close to or enter the ovary. In case of PGI $\geq 2$, it was concluded that there is compatibility.

\section{Evaluation of pollen - donor selection}

Cross pollination of flowers was performed with pollen derived from cultivars flowering at similar time periods for selected four cultivars of Asian pear ('Dangshansu Li', 'Ju Li', 'Mramornaja', 'Kumoi'). For this purpose, flowers (balloon stage) of the pollinated cultivar were emasculated and were covered with agrotextile insulators, and after the flowers opened, manual pollination was carried out with pollen of selected cultivars. Pistils' collection and microscope preparations were carried out according to the method described earlier.

\section{Statistical analysis}

The results of the experiment concerning open- and selfpollination of eight Asian pear cultivars were statistically analyzed using analysis of variance (ANOVA) and Statistica software (StatSoft Inc., v. 12, USA); the means were compared by Duncan's test, $\alpha \leq 0.05$.

\section{Results and Discussion}

\section{Evaluation of pollen quality}

Evaluation of cultivars in terms of pollination suitability should include a number of important characteristics, among others, pollen yield measured by the number of pollen grains in the flower. Table 1 shows pollen yield of 20 Asian and 5 European pear cultivars.

Pear cultivars were characterized by a similar number of anthers, from 20.0 to 26.0 (Table 1), similarly as European pear cultivars (20-30 anthers in flower) (Konarska et al., 2005).

Most Asian pear cultivars exhibited high pollen yields, with the exception of six cultivars that contained less than 1000 pollen grains in the anther, which, with a similar number of anthers compared to other cultivars, resulted in

Table 1. Pollen efficiency of European and Asian pear flowers

\begin{tabular}{|c|c|c|c|}
\hline Cultivar & $\begin{array}{l}\text { Average number } \\
\text { of anthers/flower }\end{array}$ & $\begin{array}{l}\text { Average number of pollen } \\
\text { grains in anther }\end{array}$ & $\begin{array}{c}\text { Average number of pollen } \\
\text { grains in a flower }\end{array}$ \\
\hline 'Beurré Bosc' & 23.1 & 2097.6 & 48455 \\
\hline 'Chojuro' & 20.1 & 1453.0 & 29205 \\
\hline 'Hosui' & 20.0 & 1922.3 & 38445 \\
\hline 'Jin Hua' & 20.2 & 1298.9 & 26237 \\
\hline 'Ju Li’ & 24.2 & 1752.3 & 42405 \\
\hline 'Kieffer' & 21.3 & 814.0 & 17338 \\
\hline 'Clapp's Favourite' & 24.0 & 2090.0 & 50160 \\
\hline 'Conference' & 23.5 & 1516.6 & 35640 \\
\hline 'Kum Ghant Chu' & 22.3 & 1874.4 & 41800 \\
\hline 'Alexander Lucas' & 23.0 & 877.6 & 20185 \\
\hline 'Man San' & 20.1 & 2470.9 & 49665 \\
\hline 'Mut Chen' & 22.2 & 579.7 & 12870 \\
\hline 'Nijisseiki' & 22.0 & 1905.0 & 41910 \\
\hline 'Ping Guo Li' & 22.0 & 1712.5 & 37675 \\
\hline 'Pung Su' & 22.5 & 1359.1 & 30580 \\
\hline 'Sha Li' & 22.2 & 1788.7 & 39710 \\
\hline 'Shinseiki' & 21.9 & 211.5 & 4631 \\
\hline 'Shinko' & 22.3 & 2643.9 & 58960 \\
\hline 'Dangshansu Li' & 21.9 & 452.1 & 9900 \\
\hline 'Sirinskaja' & 22.2 & 830.6 & 18439 \\
\hline 'Xue Hua Li' & 20.8 & 642.5 & 13365 \\
\hline 'Williams Bon Chrétien' & 23.2 & 1925.0 & 44660 \\
\hline 'Wujiu Xiang' & 20.3 & 1441.4 & 29260 \\
\hline 'Ya Li' & 26.0 & 1017.5 & 26455 \\
\hline 'Zao Su Li' & 22.9 & 2324.9 & 53240 \\
\hline
\end{tabular}




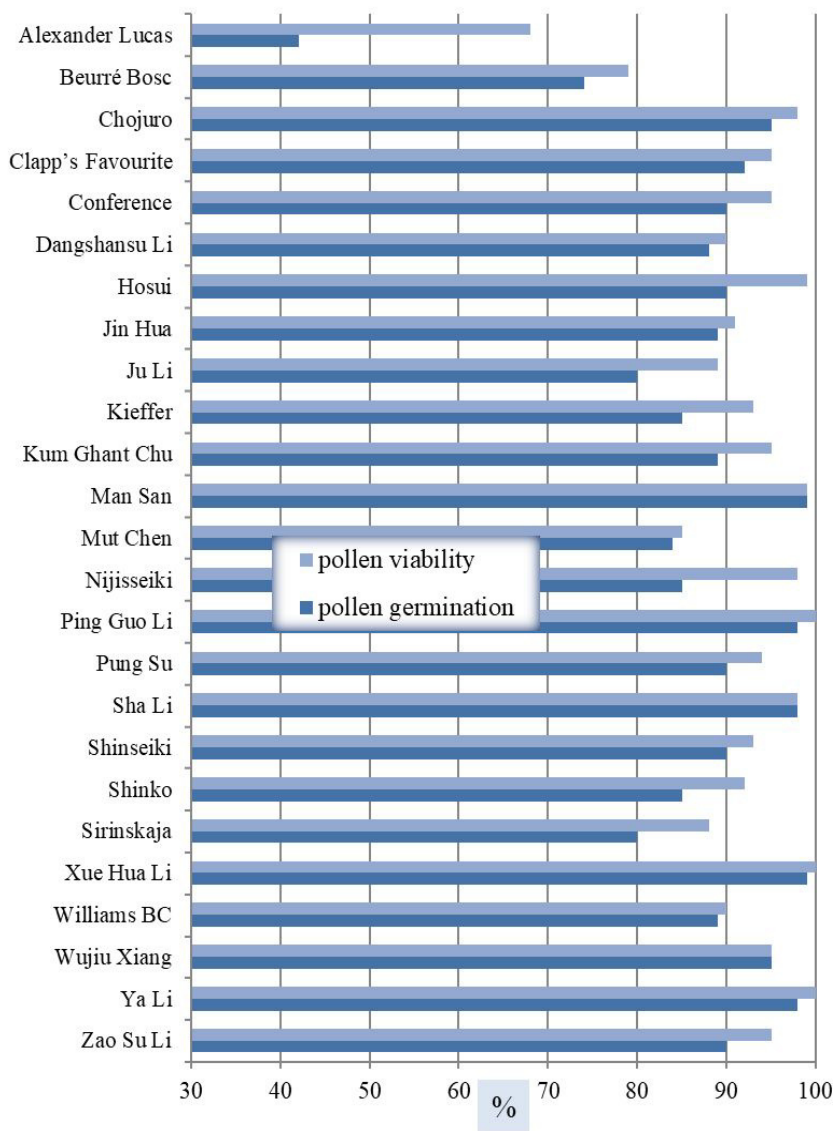

Fig. 1. Viability and germination of pollen of European and Asian pear cultivars

low pollen yields of these cultivars. Flowers of European pear cultivars, with the exception of the cultivar 'Alexander Lucas', were characterized by one of the highest pollen content in the flower, suggesting that these cultivars may be good pollen - donors of compatible varieties in fruit growing. Nogueira et al. (2016) also compared pollen yield of Asian and European pears, and found that European pear trees had significantly higher pollen yields compared to Asian pears. Pyrus communis od której pochodzi większość europejskich odmian grusz charakteryzuje się wysoką zawartością ziaren pyłku about 60,800 (Konarska et al., 2005 after Maurizio and Grafl 1969). The number of pollen grains in the anther is affected by genetic and environmental factors. Nogueira et al. (2016) reported that the cultivar Hosui was characterized by a very low pollen yield, while in our study, this cultivar had a high pollen yield and a similar number of anthers. Quinet et al. (2016) reported that the number of pollen grains in the anther of the European cultivar 'Conference' was over 2000, while in the discussed experiment, a slightly lower number of pollen grains was recorded for this cultivar. Research of Dumanoglu and Celik (1994) indicated that 'Williams' (synonym 'Bartlett') was the best pollen producer, similarly as in our experiment.

The test for pollen viability and germination capacity should always be carried out before the beginning of the cultivation work, as in the cultivar fertility experiments. In temperate climates, disturbances may occur in the process of microsporogenesis, e.g. after a severe winter (Webster 2002). Confirmation of this finding is a comparison of the discussed outcomes and a study of Nogueira et al. (2016). The cultivar 'Hosui', which in our experiment was characterized by a high percentage of pollen germination (90\%), exhibited very low germination, at the level of about $19 \%$, in the study of the aforementioned authors. Okusaka and Hiratsuka (2009) reported that the germination of the Japanese cultivar 'Kousui' (syn. 'Kosui') on a medium with the same sucrose content (10\%) was only $35 \%$. For most of the cultivars in the experiment, both pollen viability and germination capacity were very high (average viability of more than $90 \%$ and germination above $80 \%$ ), with the exception of the cultivars 'Alexander Lucas' and 'Beurré Bosc'; such pollen viability is sufficient for the matching cultivars to effectively fertilize the ovules.

Table 2. Comparison of efficiency of pollination of Asian pears depending on type of pollination

\begin{tabular}{|c|c|c|c|c|c|c|c|}
\hline Cultivar & $\begin{array}{c}\text { Type of } \\
\text { pollination }\end{array}$ & $\begin{array}{l}\text { Average number of } \\
\text { pollen on stigma }\end{array}$ & $\begin{array}{c}\text { Average number of } \\
\text { germinating pollen } \\
\text { on stigma }\end{array}$ & $\begin{array}{c}\text { Average number of } \\
\text { pollen tubes in } 1 / 3 \\
\text { length of pistil }\end{array}$ & $\begin{array}{c}\text { Average number of } \\
\text { pollen tubes in } 1 / 2 \\
\text { length of pistil }\end{array}$ & $\begin{array}{c}\text { Average number of } \\
\text { pollen tubes in } \\
\text { ovary }\end{array}$ & $\mathrm{PGI}^{* *}$ \\
\hline \multirow{2}{*}{ 'Hood' } & open - & $18.5 \mathrm{a}^{\circ}$ & $18.5 \mathrm{a}$ & $18.5 a$ & $5.2 \mathrm{a}$ & $1.8 \mathrm{a}$ & 1.9 \\
\hline & self - & $0.0 \mathrm{~b}$ & $0.0 \mathrm{~b}$ & $0.0 \mathrm{~b}$ & $0.0 \mathrm{~b}$ & $0,0 \mathrm{~b}$ & 0.0 \\
\hline \multirow{2}{*}{ 'Jin Hua' } & open - & 127.1a & 127.1a & 127.1a & $29.0 \mathrm{a}$ & $12.2 \mathrm{a}$ & 2.2 \\
\hline & self - & $30.1 \mathrm{~b}$ & $30.1 \mathrm{~b}$ & $18.9 \mathrm{~b}$ & $2.6 \mathrm{~b}$ & $0.4 \mathrm{~b}$ & 1.1 \\
\hline \multirow{2}{*}{ 'Ju Li' } & open - & $92.6 \mathrm{a}$ & $92.6 \mathrm{a}$ & $92.6 \mathrm{a}$ & $13.1 \mathrm{a}$ & $2.3 \mathrm{a}$ & 2.2 \\
\hline & self - & $43.5 b$ & $43.5 b$ & $34.6 \mathrm{~b}$ & $2.2 \mathrm{~b}$ & $0.2 b$ & 1.1 \\
\hline \multirow{2}{*}{ 'Kieffer' } & open - & $46.9 a$ & $46.9 a$ & $46.4 a$ & 10.1a & $3.9 a$ & 1.9 \\
\hline & self - & $0.0 \mathrm{~b}$ & $0.0 \mathrm{~b}$ & $0.0 \mathrm{~b}$ & $0.0 \mathrm{~b}$ & $0.0 \mathrm{~b}$ & 0.0 \\
\hline \multirow{2}{*}{ 'Conference' } & open - & $78.7 \mathrm{a}$ & $78.7 \mathrm{a}$ & $78.7 \mathrm{a}$ & $8.5 \mathrm{a}$ & $3.7 \mathrm{a}$ & 2.2 \\
\hline & self - & $20.1 \mathrm{~b}$ & $20.1 \mathrm{~b}$ & $6.0 \mathrm{~b}$ & $0.0 \mathrm{~b}$ & $0.0 \mathrm{~b}$ & 0.9 \\
\hline \multirow{2}{*}{ 'Ping Guo Li' } & open - & $146.5 \mathrm{a}$ & $146.5 a$ & 146.1a & $25.6 a$ & $4.3 \mathrm{a}$ & 2.2 \\
\hline & self - & $39.0 \mathrm{~b}$ & $41.3 \mathrm{~b}$ & $7.5 b$ & $0.5 b$ & $0.0 \mathrm{~b}$ & 0.9 \\
\hline \multirow{2}{*}{ 'Wujiu Xiang' } & open - & $85.2 \mathrm{a}$ & $85.2 \mathrm{a}$ & $85.2 a$ & $15.7 \mathrm{a}$ & 7.1a & 2.2 \\
\hline & self - & $0.0 \mathrm{~b}$ & $0.0 \mathrm{~b}$ & $0.0 \mathrm{~b}$ & $0.0 \mathrm{~b}$ & $0.0 \mathrm{~b}$ & 0.6 \\
\hline \multirow{2}{*}{ 'Zao Su Li' } & open - & $111.5 \mathrm{a}$ & $111.5 \mathrm{a}$ & $110.4 a$ & $11.1 \mathrm{a}$ & $3.3 \mathrm{a}$ & 2.1 \\
\hline & self - & $41.4 \mathrm{~b}$ & $41.3 \mathrm{~b}$ & $41.0 \mathrm{~b}$ & $3.3 b$ & $0.5 b$ & 1.4 \\
\hline
\end{tabular}

For cultivar values followed with different letters differ significantly at probability $\alpha=0.05$

${ }^{* *}$ PGI = Pollen Germination Index 
Table 3. Evaluation of self-fertility of chosen pear cultivars (after self-pollination)

\begin{tabular}{|c|c|c|c|c|c|c|}
\hline Cultivar & $\begin{array}{l}\text { Average number of } \\
\text { pollen on stigma }\end{array}$ & $\begin{array}{c}\text { Average number of } \\
\text { germinating pollen on } \\
\text { stigma }\end{array}$ & $\begin{array}{l}\text { Average number of } \\
\text { pollen tubes in } 1 / 3 \\
\text { length of pistil }\end{array}$ & $\begin{array}{l}\text { Average number of } \\
\text { pollen tubes in } 1 / 2 \\
\text { length of pistil }\end{array}$ & $\begin{array}{l}\text { Average number of } \\
\text { pollen tubes } \\
\text { in ovary }\end{array}$ & $\mathrm{PGI}^{*}$ \\
\hline 'Chojuro' & 115.0 & 113.6 & 3.5 & 2.0 & 0.0 & 1.0 \\
\hline 'Hosui' & 4.8 & 4.8 & 4.0 & 0.0 & 0.0 & 1.3 \\
\hline 'Jin Hua' & 8.1 & 8.1 & 2.5 & 0.5 & 0.4 & 0.9 \\
\hline 'Kum Ghant Chu’ & 17.4 & 17.4 & 0.0 & 0.0 & 0.0 & 0.9 \\
\hline 'Man San' & 36.3 & 35.0 & 12.3 & 3.8 & 0.2 & 1.2 \\
\hline 'Mut Chen' & 37.3 & 37.3 & 5.0 & 0.7 & 0.0 & 1.2 \\
\hline 'Nijisseiki' & 27.6 & 27.6 & 0.8 & 0.3 & 0.2 & 1.2 \\
\hline 'Pung Su' & 5.6 & 5.6 & 0.0 & 0.0 & 0.0 & 0.7 \\
\hline ‘Sha Li’ & 5.0 & 5.0 & 3.1 & 2.7 & 0.0 & 0.7 \\
\hline 'Shinko' & 68.6 & 62.0 & 18.9 & 13.7 & 0.0 & 1.2 \\
\hline 'Shinseiki' & 2.0 & 2.0 & 1.0 & 0.0 & 0.0 & 0.6 \\
\hline 'Dangshansu Li' & 0.9 & 0.3 & 0.0 & 0.0 & 0.0 & 0.7 \\
\hline 'Xue Hua Li' & 1.3 & 1.3 & 4.2 & 0.9 & 0.0 & 0.7 \\
\hline 'Ya Li' & 46.0 & 46.0 & 25.3 & 0.0 & 0.0 & 0.8 \\
\hline
\end{tabular}

\section{Evaluation of self-fertility}

Self-fertility of selected pear cultivars was evaluated on the basis of microscopic observations of the number of pollen grains on the stigma and the pollen tube overgrowth through the pistil style to the ovary (Table 2). The pollination efficiency was compared in eight pear cultivars, as a result of free pollination by insects and manual pollination with their own pollen. Knowledge of selfincompatibility of pear cultivars may be useful in planning pear orchards in terms of selecting best pollen - donors.

Significantly higher values were found for all the traits discussed for all cultivars after comparing the two methods of pollination. For the cultivars 'Hood', 'Kieffer' and 'Wujiu Xiang' in combination pollinated with own pollen, no pollen was found on the pistil stigmas suggesting strong selfincompatibility already on the stigma. The calculated pollen germination index (PGI) showed the level of selfincompatibility of the discussed cultivars. PGI $>1$ was found for five cultivars, indicating strong self-incompatibility, while for the three cultivars, PGI was slightly above 1 . Cultivars pollinated freely by insects with a mixture of many cultivars blooming in the orchard were characterized by a PGI value of more than 2 , which indicated high pollen compatibility with the pollinated cultivar. Wojciechowski and Antkowiak (2009) classified pear compatibility levels according to the PGI. If the index value is 1.2-1.9, it means that the cultivars are an unilateral cross - incompatible, and in the case of values of 2 and above, the cultivars are fully cross-compatible.

As presented in Table 2, PGI did not exceed the 1.2 value for most cultivars after pollination with own pollen, except for the cultivar ' $\mathrm{Zao} \mathrm{Su} \mathrm{Li}$ ', which indicated that these cultivars are not self-fertile. Therefore, pollen - donor is required in the orchard to obtain good fruits of good quality.

In the next stage of cultivar self-pollination evaluation manual pollination of flowers with their own pollen was performed. The degree of Asian pear self-fertility was determined, based on the microscopic observation of pollen tube overgrowth through the pistil tissue (Table 3).

In the case of manual pollination, a large number of pollen grains is applied to the stigma. In the orchard, a large number of pollen grains on the stigma is dependent on the presence and activity of a sufficient number of insects. According to Zang et al. (2010) higher levels of pollen density improved seed viability, fruit set, and fruit quality. Treatments with the highest pollen density showed significantly increased fruit growth rate and larger fruits at harvest. High pollen density increased germination rate and resulted in a faster pollen tube growth. A large number of pollen grains on the stigma enables competition of pollen tubes at the time of growth through the pistil tissue. This means that the strongest tubes are involved in the ovule fertilization, thereby the resulting seedlings are characterized by a high vigor (Janse and Verhaegh, 1993).

If the pollen is compatible with the stigma, then after about 30 minutes a permanent connection is formed between the stigma and the pollen grain, which does not allow the pollen to be flushed (Śnieżko and Winiarczyk, 1993). The results from Table 3 show that the number of pollen grains on the stigmas highly varied: from just a few to several dozen pollen grains. Consequently, on the stigmas pollinated with own pollen, there was no interaction between the stigma tissue and pollen grains, which made the pollen very easily flushed. Rain or dew may cause flushing of incompatible pollen under field conditions, while the preparation procedure may cause it under laboratory conditions (Fig. 2D). The above observations suggest that self-incompatibility in cultivars with a small number of pollen grains on the stigma, is already revealed on the stigma. Yamashita et al. (1990) suggested that the stigma might play a significant role in the incompatibility mechanism of Japanese pear. This characteristic can also manifest at various stages of pollen tube growth through the pistil tissue. As regards compatible cultivars, the pollen grains germinated on the stigma and freely overgrew the pistil to the ovary (Fig. $2 \mathrm{~A}, \mathrm{C}$ ). If the cultivar is characterized by partial incompatibility, pollen tubes begin to die off in $1 / 3$ or half the length of the pistil (Fig. 2B). The PGI index summarizes the above characteristics. For 'Hosui', 'Mut Chen', 'Man San', and 'Nijisseiki' cultivars, the PGI index indicated poor selffertility; the remaining cultivars had a PGI index below 1 , which indicated a strong self-incompatibility. There are about 10 ovules in the the ovary of pear flowers, therefore the 


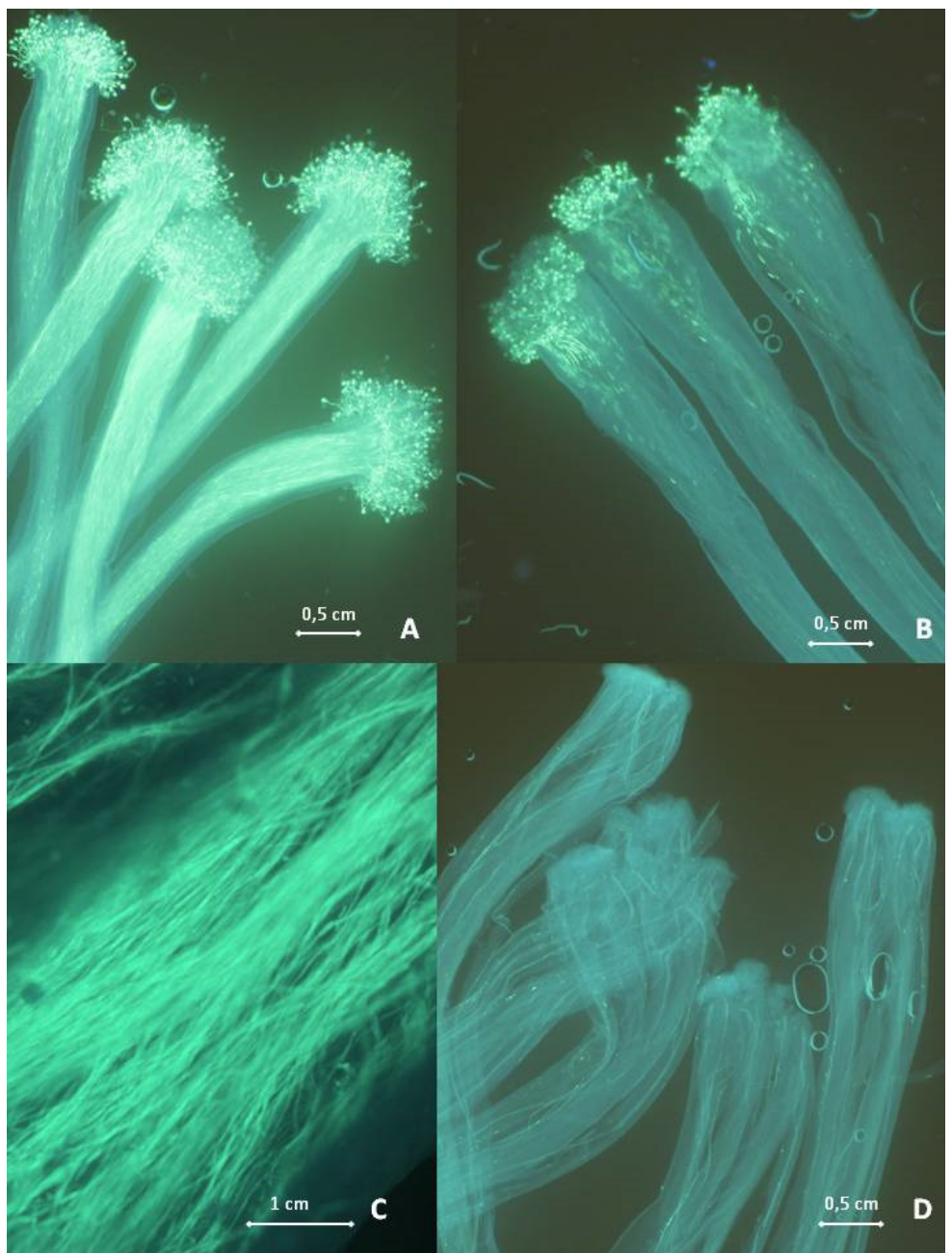

Fig. 2. Pollen germination and pollen tubes growth depending on the type of pollination of Asian pear cultivars. A. Stigma with germinating pollen grains and numerous pollen tubes growing through the pistil after open pollination. B. Pollen tubes growth arrested at $1 / 3$ of pistil length after self-pollination. C. Numerous pollen tubes are visible in half length of pistil after openpollination. D. Stigmas without pollen grains after self-pollination

number of pollen tubes necessary for sufficient ovule fertilization and seed formation should be at least 10 . According to Hiratsuka et al. (2012), the correct development of pear fruits occurs when the fruit contains at least 7 seeds. In the present study, most of the cultivars, except for 'Shinko', exhibited growth inhibition of pollen tubes below $1 / 3$ of the pistil length and the number of pollen tubes growing into the ovary was minimal.

\section{Evaluation of pollen - donor selection}

This study was undertaken to determine the compatibility between Asian pear cultivars that were pollinated with pollen of European and Asian cultivars. For this purpose, a series of crosses was performed for four cultivars of Asian pear: 'Dangshansu Li', 'Mramornaja', 'Ju Li' and 'Kumoi' (Fig. 3 A, B, C, D).

In the case of compatible cultivars, pollen tubes easily grew throughout the entire length of the pistil style to the ovary, whereas there was a noticeable inhibition of the growth of the pollen tubes at half the length of the pistil style for non-compatible cultivars. Fig. 3 shows the percentage of pistils with pollen tubes visible at half the length of the pistil and the percentage of ovaries with pollen tubes growing into them. The percentage of pistils with pollen tubes at half the length of the pistil in crosses of cultivars: 'Dangshansu Li' $\times$ 'Conference', 'Dangshansu Li' $\times$ 'Beurré Bosc' (Fig. 3A), 'Mramornaja' $\times$ 'Williams Bon Chrétien' (Fig. 3B) and 'Ju Li' $\times$ 'Clapp's Favourite' (Fig. $3 \mathrm{C}$ ) ranged from $67 \%$ to $90 \%$, indicating a weaker incompatibility between the crossed cultivars. The presence of pollen tubes in the ovary was observed from $28 \%$ to $71 \%$ for the first three crosses, 3B) for ' $\mathrm{Ju} \mathrm{Li'} \times$ 'Clapp's Favourite' (Fig. 3C) incompatibility was found below half the length of the style, as evidenced by the lack of pollen tubes in the ovary. The percentage of pollen tubes below the $20 \%$ value at half the length of the pistil suggested a strong incompatibility between the crossed cultivars (Fig. 3 ABCD). Since Asian pears are generally not self compatible, they required pollination by other cultivar, often European pears are good pollen-donor (Rohitha 1989). After crossing European and Asian pear cultivars, Antkowiak and Wojciechowski (2006) have found a total or partial incompatibility between the crossed pear cultivars. Arzani $e t$ al. (2005) have studying nine Asian pear cultivars, and based on the field and in vitro pollen tube growth tests they have found cross-compatibility between some cultivars. 

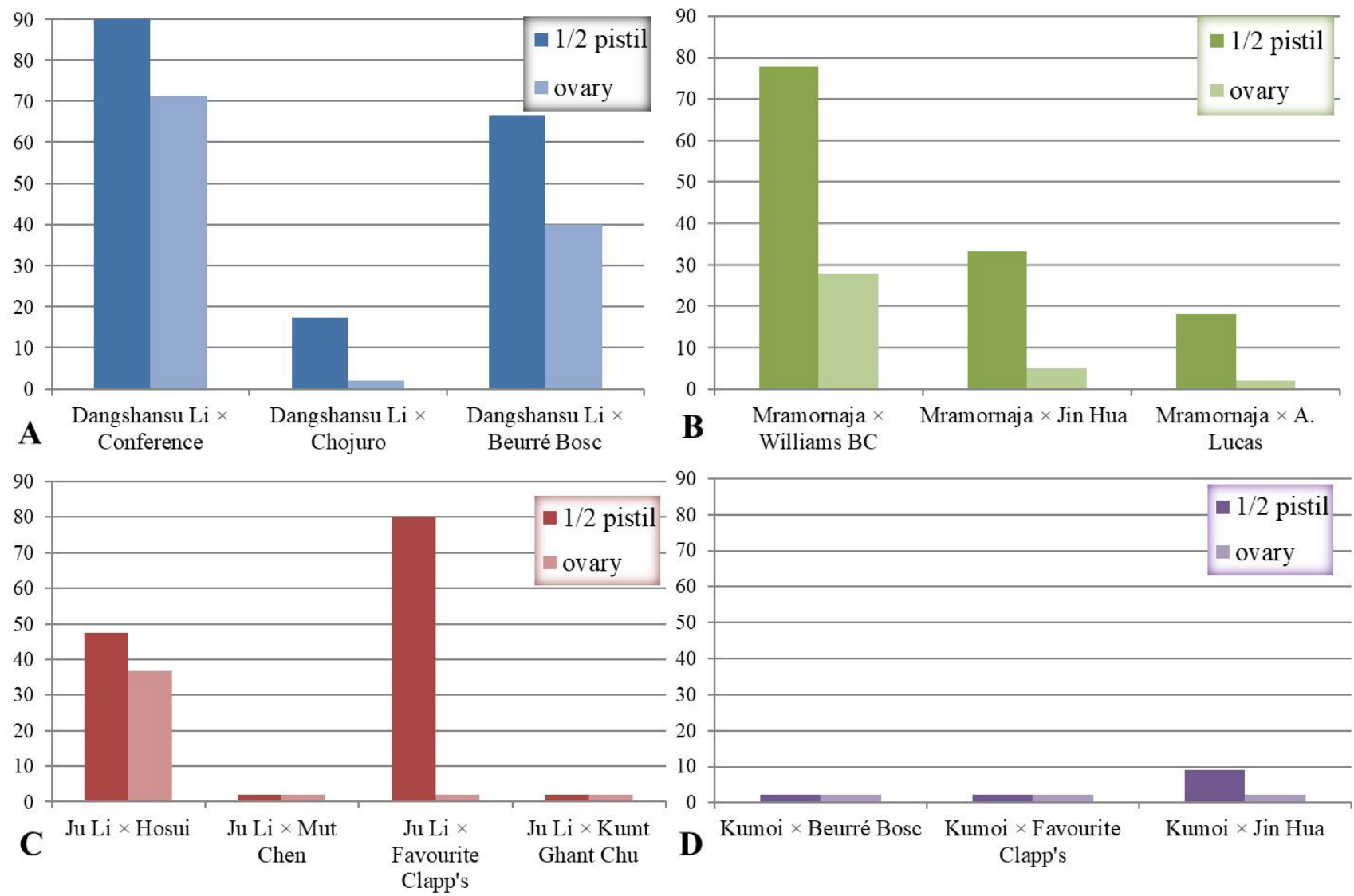

Fig. 3. The percentage of pollen tubes growing up to half the pistil length and growing into the ovary after cross-pollination of four Asian pear cultivars (A - 'Dangshansu Li', B - 'Mramornaja', C - 'Ju Li', D - 'Kumoi')

\section{Conclusions}

Several conclusions can be drawn from the study. Flowers of most Asian pear cultivars are characterized by high pollen yields, the viability and germination ability of pollen. The above features indicate that most of these cultivars are potential good pollinators, after matching pairs of cultivars in the orchards. The fertility of pear cultivars can be evaluated on the basis of the observation of pollen tube overgrowth through the pistil to the ovary and the PGI index. Based on the PGI coefficient it was found that none of the tested cultivar was self-fertile. The greatest compatibility was found between 'Dangshansu Li' $\mathrm{x}$ 'Conference' cultivars.

\section{Acknowledgements}

This work was supported by the Polish Ministry of Higher Education DS 3500.

\section{References}

Alexander MP (1969). Differential staining of aborted and nonaborted pollen. Stain Technology 44:117-122.

Antkowiak W, Wojciechowski A (2006). The evaluation of selfcompatibility and cross ability in the genus Pyrus based on the observation of pollen tube growth. Acta Agrobotanica 59(1):91-97.
Arzani K, Koushesh-Saba M, Ghanati F (2005). Study on compatibility and pollen tube growth of some Asian pear (Pyrus serotina REHD.) cultivars. Acta Horticulture 671:159-163.

Benedek P (2003). Bee pollination of fruit trees: Recent advances and research perspectives I.Journal of Apicultural Science 47(1):87-94.

Dumanoglu H, Celik M (1994). Pollen production of some pear (Pymus communis L.) cultivars. Acta Horticulturae 367:97-99.

Farkas Á, Orosz-Kovács Zs, Szabó G (2002a). Insect attraction of flowers in pear cultivars. Acta Horticulturae 596:773-776.

Farkas Á, Szabó G, Orosz-Kovács Zs (2002b). Nectar composition in some pear cultivars. Acta Horticulturae 596:761-764.

Farkas Á, Orosz-Kovács Zs (2004). Primary and secondary attractants of flowers in pear Pyrus betulifolia. Acta Horticulturae 636:317-324.

Hiratsuga A, Fujimura M, Hayashida T, Nishikawa Y, Nada K (2012). Pollen factors controlling self-incompatibility strength in Japanese pear. Sexual Plant Reproduction 25:347-352.

Honty K, Göndör M, Boldog Z, Horvath Z, Szami Z (2003). Growing experiences of the Japanese pear in Hungary, and evaluation their hybrids. Eucarpia Symposium on Fruit Breeding and Genetics (Angers - France, 1-5.09.2003). Programme and Abstracts, pp. 136.

Jacquemart AL, Michotte-Van Der AA A, Raspe O (2006). Compatibility and pollinator efficiency tests on Pyrus communis L. cv. Conference. Journal of Horticultural Science \& Biotechnology 81(5):827-830. 
382

Jacquemart AL (2007). Methods for determining compatibility and pollen - donor efficiency in temperate fruit species. Fruit, Vegetable and Cereal Science and Biotechnology 1(1):26-38.

Janse J, Verhaegh JJ (1993). Effects of varying pollen load on fruit set, seed set and seedling performance in apple and pear. Sexual Plant Reproduction 6(2):122-126

Konarska A, Masierowska M, Weryszko-Chmielewska E (2005). The structure of nectaries and nectar secretion in common pear (Pyrus communis L.) Journal of Apicultural Science 49(1):85-92.

LiTSC (2002). Asian pears in Canada. Acta Horticulturae 587:129-131.

Maccagnani B, Ladurner E, Santi F, Burgio G (2003). Osmia cornuta (Hymenoptera, Megachilidae) as pollinator of pear (Pyrus communis): fruit-and seed-set. Apidologie 34:207-216.

Monzón V, Bosch J, Retana J (2004). Foraging behavior and pollinating effectiveness of Osmia cornuta (Hymenoptera, Megachilidae) and Apis mellifera (Hymenoptera; Apidae) on 'Comice' pear. Apidologie 35:575585.

Martin F (1959). Staining and observing pollen tubes by means of fluorescens. Stain Technology 34:125-128.

Matsuzava Y (1983). Studies of the interspecific hybridization in genus Brassica. II. Cross stability in interspecific crosses $B$. oleracea $\times B$. campestris.Japan J. Breed 33:321-330.

Nogueira PV, Coutinho G, Pio R, da Silva DF, Zambon CR (2016). Establishment of growth medium and qualification of pollen grains and germination of pear tree cultivars. Revista Ciência Agronômica 47(2):380-386.

Okusaka K, Hiratsuka S (2009). Fructose inhibits pear pollen germination on agar medium without loss of viability. Scientia Horticulturae 122:5155.

Pitera E, Odziemkowski S (2004). Evaluation of three Asian pear cultivars for cultivation in commercial orchards. Journal of Fruit and Ornamental Plant Research 12:83-88.

Quinet M, Warzée M, Vanderplanck M, Michez D, Lognay G, Jacquemart $\mathrm{AL}$ (2016). Do floral resources influence pollination rates and subsequent fruit set in pear (Pyrus communis L.) and apple (Malus $\times$ domestica Borkh) cultivars? European Journal of Agronomy 77:59-69.
Rohitha BH (1989). Pollination compatibility between commercial nashi (Pyrus serotine Rehder var cutta Rehder) cultivars in New Zealand and 'Louise Bonne de Jersey' pear. New Zealand Journal of Crop and Horticultural Science 17:109-111.

Sanzol J, Rallo P, Herrero M (2003a). Asynchronous development of stigmatic receptivity in the pear (Pyrus communis; Rosacea) flowers. American Journal of Botany 90(1):78-84.

Sanzol J, Rallo P, Herrero M (2003b). Stigmatic receptivity limits the effective pollination period in 'Agua de Aranjuez' pear. Journal of American Society and Horticultural Science 128(4):458-462.

Shin YU, Kim WC, Moon JY (1988). Studies on the selection of suitable pollinizers for the 'Niitaka' pear cultivar. Journal of the Korean Society of Horticultural Science 29:109-113.

Śnieżko R, Winiarczyk K (1993). Znamię i pyłek - przegląd prac dotyczacych zgodnego zapylenia [Stigma and pollen - review of articles concerning compatible pollination (in Polish)]. Wiadomości Botaniczne 37(1/2):31-41.

Webster AD (2002) Factors influencing the flowering, fruit set and fruit growth of European pears. Acta Horticulturae 596:699-709.

Wojciechowski A, Antkowiak W (2009). Selection of pollen - donors for particular pear cultivars (Pymus communis L.) based on the observation of the pollen tubes. Herba Polonica 55(3):257-265.

Yamashita K, Saita H, Hashimoto N (1990). Pollen-stigma interaction which might be critical top the gametophytic incompatibility of Japanese pear. Journal of the Japanese Society for Horticultural Science 59(1):83-89.

Zhang C, Tateishi N, Tanabe K (2010). Pollen density on the stigma affects endogenous gibberellin metabolism, seed and fruit set, and fruit quality in Pyruspyrifolia. Journal of Experimental Botany 61(15):4291 4302.

Zisovich AH, Goldway M, Shneider D, Steinberg S, Stern E, Stern RA (2012). Adding bumblebees (Bombus terrestris L., Hymenoptera: Apidae) to pear orchards increases seed number per fruit, fruit set, fruit size and yield. Journal of Horticultural Science \& Biotechnology $87(4): 353-359$. 